\title{
Intestinal Metaplasia of Antral Superficial-foveolar Epithelium in Children with Atrophic Gastritis
}

\author{
Atrofik Gastritli Çocuklarda Antral Yüzeyel-foveolar Epitelin Intestinal Metaplazisi
}

\author{
Natalia Yurievna Shirokova, Natalia Yurievna Orlinskaya, Diana Anatolyevna Davydova \\ Federal State Budgetary Institution "Privolzhsky Federal Research Medical Centre" of the Ministry of Health of the Russian Federation, \\ Department of Autopsy, Nizhny Novgorod, Russia
}

\begin{abstract}
Aim: Chronic gastritis (CG), being one of the most common digestive diseases, is frequently underestimated both by patients and clinicians. However, CG developed as early as in childhood, and often accompanied by Helicobacter pylori contamination of antral mucus, has a persistent recurrent course in adult patients, complicated by mucosal transformations in the form of atrophy, metaplasia and dysplasia. CG can appear as an early stage in the morphogenesis of tumor growth. From this point of view, CG is worth noticing. Materials and Methods: A complex morphological study of antral mucosa in school children with atrophic gastritis has been performed using histochemistry, immunohistochemistry and a morphometric methods.

Results: In atrophic gastritis we have revealed the decrease in the number of functionally mature cells responsible for the production of extracellular matrix and basal membrane components, the lack of which in paraepithelial localization results in the change of their special properties. In addition, sulphomucins, non-characteristic of stomach, overlapped on mucosa and in single foveolae have been found in atrophic gastritis.

Conclusion: Permanent impairment in the conjugation of cell and tissue components in mucosa accompanied by the change of an epithelial layer synthetic function with the impaired physicochemical properties of gastric mucin results in intestinal metaplasia as early as in childhood.

Keywords: Gastritis, intestinal metaplasia, regeneration, mucin
\end{abstract}

ÖZ

Amaç: Çocukluk çağının en sık görülen sindirim sistemi problemlerinden olan kronik gastrit (KG) çoğu kez hastalar ve klinisyenler tarafindan küçümsenmektedir. Halbuki çocuklukta başlayıp sıkıkla antral mukusun Helicobacter pylori ile bulaşının eşlik ettiği KG, erişkin dönemde atrofi, metaplazi ve displazi gibi mukoza değişiklikleriyle komplike olan kalıcı, yineleyen bir seyir izlemektedir. KG tümör gelişimi morfogenezinin erken bir evresi olarak ortaya çıkabilir. Bu bakış açısılla, KG dikkate alınması gereken bir patolojik durumdur.

Gereç ve Yöntemler: KG'li okul çocuklarinda, histokimyasal, immünohistokimyasal ve morfometrik yöntemlerle antral mukozanın ayrntıtı morfolojik değerlendirilmesi gerçekleştirimiş̧ৃir.

Bulgular: Atrofik gastritte, paraepitelyal bölgedeki yoklukları, kendilerine özgül özelliklerin değişimiyle sonuçlanan ekstraselüler matriks ve bazal membran bileşenlerinin üretiminden sorumlu fonksiyonel yönden matür hücrelerin sayısında azalma saptadık. Buna ek olarak, yine atrofik gastrik örneklerinde midenin karakteristik bileşeni olmayan sülfomüsinlerin mukoza ve tekli foveolalarda birikimi saptand.

Sonuç: Hücre ve doku bileşenlerinin bağlanımındaki kalııı hasar ve buna eşlik eden epitelyal tabakanın sentetik fonsiyonunun değişimiyle birlikte gastrik müsinin bozulmuş fizikokimyasal özellikleri, çocukluk çağı gibi çok erken bir dönemde intestinal metaplaziye yol açmaktadır.

Anahtar Kelimeler: Gastrit, intestinal metaplazi, rejenerasyon, müsin 


\section{Introduction}

Chronic gastritis (CG), being one of the most common digestive diseases, is frequently underestimated both by patients and clinicians (1-3). However, CG developed as early as in childhood, and often accompanied by Helicobacter pylori contamination of antral mucus, has a persistent recurrent course in adult patients complicated by mucosa transformations in the form of atrophy, metaplasia and dysplasia. CG can appear as an early stage in the morphogenesis of tumor growth $(4,5)$. From this point of view, CG is worth noticing $(6,7)$.

According to the majority of experts in intestinal metaplasia (IM), which is able to act as precursor of neoplastic processes, the failure of epithelial cell differentiation occurs after epithelial layer damage $(8,9)$. This has been supported by the studies carried out over the last years. According to their data, undifferentiated cells pre-existing in gastric epithelium can be differentiated by uncharacteristic intestinal type under certain unfavorable conditions. In addition, the disorders in cell differentiation are not due to drastic genome changes but determined by physico-chemical factors, which have an impact on them (10-12). And the formation of further transformations against the background of IM is due to its expansion and the character of mucins produced by epithelium (13-15).

However, in modern literature the causes and mechanisms of gastric epithelial IM formation (16-18) still remain underinvestigated, and they are mainly represented by the studies of cell kinetics, the activity and intensity of inflammatory changes in adult population (19-21).

The present study aims to investigate the structural framework origin of the competence of the regeneration processes in antral mucosa (AM) with IM for the early optimization of the management and prevention of the formation of further neoplastic processes, as well as the implementation of the possibility of epithelium with metaplasia to regress and become normal. Therefore, the study of the biopsy material from children seems to be the most relevant objective (22-25).

The objective of this study was to determine the disorders of epithelial stromal relations contributing to the formation of a quite new epithelium in the form of IM foci in AM in children.

\section{Materials and Methods}

The present study is an observational, retrospective, analytical case-control. The materials were the antral biopsies of 7 to 16-year-old 1367 children with chronic gastroduodenitis, undergoing treatment at the clinic of Nizhny Novgorod Research Institute of Pediatric Gastroenterology over the period of 2001-2012. The patients underwent endoscopic and morphological examination in a strict accordance with the management algorithm of a gastrointestinal patient. All patients gave their informed consent to undergo medical procedures and satisfied the requirements of the Local Ethics Committee of Nizhny Novgorod Research Institute developed according to World Medical Association's Declaration of Helsinki (2000) (approval number: 2007/28). Morphologic and functional assessment of gastric mucosa biopsies, the character of Helicobacter pylori contamination were performed in accordance with Sydney system classification, while the severity degree was evaluated according to Classification and Grading of Gastritis, Houston (26-28).

The retrospective analysis of $\mathrm{AM}$ histological examinations over the period of 2001-2012 enabled to pick out children with gastroduodenitis from a group of children $(n=42)$ who had undergone multiple (not less than 4) courses of treatment in the clinic, and over the last years were diagnosed with nonatrophic gastritis associated with Helicobacter pylori with ,+++ invasion degree, and in the last admissions they were found to have atrophic gastritis. Morphological study of AM in 42 patients with atrophic gastritis revealed IM in 11 cases.

The patients were classified into the following groups depending on the nature of changes in AM:

Group 1 (comparison group). Helicobacter pylori associated non-atropic gastritis patients with a contamination degree of,$+++(n=30)$,

Group 2. Atrophic antrum-gastritis patients without IM $(n=31)$,

Group 3. Atrophic antrum-gastritis patients with IM $(n=11)$.

Biopsy material obtained by gastroesophageal endoscopy was embedded in $10 \%$ buffered formalin $(\mathrm{pH}:$ 7.2-7.4) and exposed to standard histological treatment (dehydration, de-embedding), and paraffin sections of $5 \mu \mathrm{m}$ in thickness were received. The prepared microsections were hematoxylin and eosin stained. Histochemical identification of mucins produced by AM epithelial cells was performed using periodic acid-Schiff (PAS)-alcian blue stain in $\mathrm{pH} 2.5$. The intensity of mucin staining was estimated by semiquantitative method in scores: (+)-weak; $(++)$-moderate; $(+++)$-high. Concurrently, we carried out an immunohistochemical reaction using Muc2, Muc5AC and Muc6 markers ("Novocastra"). Mast cells were defined using basic brown, and classified according to maturation, granulation degree, and location in mucosa. Immunohistochemistry was performed to assess the intensity of the renewal processes of gastric mucous epithelium using antibodies to Ki-67 antigen (MIB-1, "Novocastra") expressed in all phases of a cell cycle. The antigen was de-shielded in citrate buffer $(\mathrm{pH} \mathrm{6.0)}$ in boiling water bath within $1 \mathrm{~h}$. NovoLink Polymer Detection System was used to reveal the expression of the markers $(29,30)$. 3.3-diaminobenzidine tetrachloride was used as chromogen. Cell nuclei were counterstained by hemalum within 2 min. By means of 400-fold magnification of a microscope, proliferation index (nuclear label Ki-67) was defined as a percentage of positively stained nuclei of epithelial cells of AM in 10 randomly chosen visual fields. Histologic specimens were examined and photographed using Nikon Eclipse E400 microscope with Nikon DS-Fi2 camera and software NIS- 
Elements Basic Research. For an objective study, the gastric mucosa structure was examined morphometrically. Cells were counted in $10 \mathrm{~F}$ v., field lens 90 and ocular lens 10, and then the absolute number of cells per $1 \mathrm{~mm}^{2}$ was calculated.

The results of the study were statistically processed. We determined the indices of descriptive statistics, the normalcy of distribution was checked using Kolmogorov-Smirnov test. Since the data distribution failed to match the normal distribution criteria, non-parametric Mann-Whitney $U$ test was used in the statistical processing of the data. $P=0.05$ was taken as the critical level in statistical hypothesis testing.

\section{Results}

AM in non-atrophic antrum-gastritis (group 1) was characterized by structural alterations indicating the development of chronic catarrhal damage. Diffuse inflammatory infiltration was found in $67 \%$ of the cases, and surface infiltration in 33\%. Superficial-foveolar epithelium over much of the mucosa was flattened, moderately infiltrated by inter-epithelial lymphocytes with insignificant content of eosinophils and neutrophils. Mucous cells showed a low degree of dystrophy with irregular mucoid production in cells. Neutral and acid mucopolysaccharide staining on epithelial surface revealed a mainly small and moderate amount of mucus located between the folds. PAS-positive staining of mucous cells covered just from $1 / 4$ to $1 / 2$ of the cell area versus $2 / 3$ of the norm that indicated their low functional activity.

In the AM stromal compartment, the edema and fullblood vessels of microvasculature were associated with high cell density infiltration. Throughout the subepithelial zone and proper mucous plate (PMP) there was an increased vessel formation (microvasculature), most vessels had a dilated lumen, thickened wall with distended nuclei of endotheliocytes, some of which had sludge phenomenon of red blood cells.

Lymphocytes were dominant in inflammatory cell infiltrates in all cases, and among them there were plasma cells with different maturity degrees. A moderate number of eosinophils and neutrophils was determined. The number of fibroblastic cells had a tendency to decrease (Table I). Such a morphological picture with a long-time persistence of mononuclear infiltrate, with an inflammatory component prevailing, leads to the accumulation of toxins damaging epithelial cytoskeleton with intercellular structure weakening, resulting in the limitation of cell functional capabilities in the quality and quantity of mucus production.

In AM atrophic changes, 98\% of the cases showed no Helicobacter pylori microbial invasion. Lymphoid follicles without cleared germinal centers were formed in $16 \%$ of observations. Focal proliferation of connective tissue in PMP was found in all cases, with collagen fibers locating predominantly between the glands without changing their contour. The epithelial surface had a small amount of mucus containing generally neutral mucopolysaccharides.
The inflammatory and dystrophic changes in groups of atrophic gastritis patients with and without intestinal metaplasia did not differ significantly. In contrast to the comparison group, lymphocytes predominated in the inflammatory infiltrates in these groups, while plasma cells were minimal, and neutrophils and eosinophils were represented by single cells. Alongside with that there was moderate dystrophy of both superficial-foveolar epitheliocytes and mucous cells with distended nuclei.

Detailed study of the AM biopsies of group 2 children (atrophic gastritis without IM) showed formed structural changes. Mucosa was characterized by the reduced height of surface epithelium, flattened epitheliocytes in both surface and foveolar epithelium with nuclei displacement in central parts of the cells, and preservation of clear cell boundaries. In addition, the functionalities of epithelium remained unchanged, which was confirmed by the sufficient synthesis of superficial-foveolar and glandular epithelium of corresponding mucins.

Basal membrane in some areas was loosened, and the intensity degree of its PAS-positive staining varied from slightly intense $(+)$ to maximum intense $(+++)$.

Against the general background of PAS-positive secretion produced by the epitheliocytes of superficialfoveolar epithelium, the appearance of alcyanophil secretion overlapping the mucosa in the gaps between single foveae in $3.3 \%$ of the histologic specimens of group 2 drew attention (Figure 1).

There was a total reduction in the number of gastric foveae, and tendency of the mucosa to preserve and maintain cytoarchitecture accompanied by the formation of deepened, tortuous and concrescent (two-chambered) foveae. Proliferative activity of the superficial-foveolar area was higher compared to that of the comparison group $(p=0.04)$ (Figure 2), and there was no significant change of this parameter when compared to group $3(p=0.091)$.

Infiltrate cell density in the interfoveolar space in antral PMP in group 2 children was significantly lower $(p=0.013)$ than that in the comparison group (group 1). In PMP,

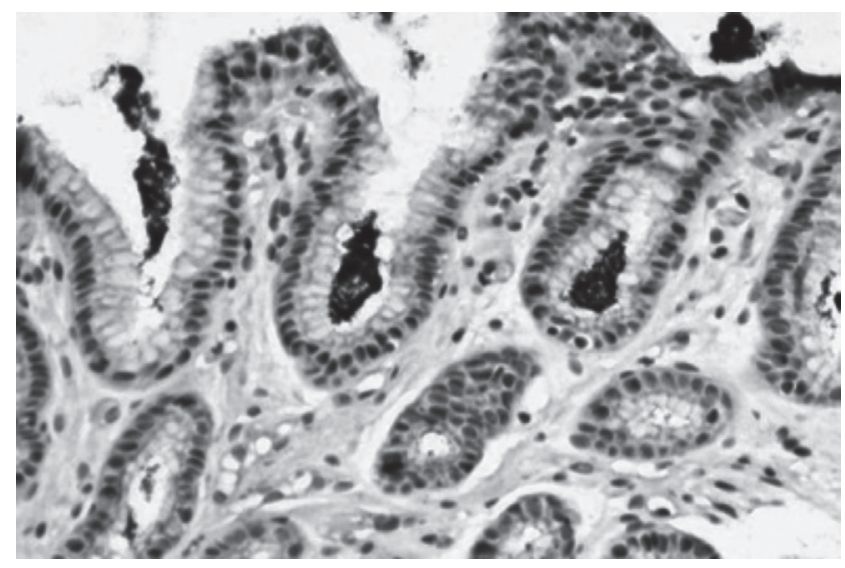

Figure 1. Immunohistochemical analysis: Muc2 expression in mucus overlapped in mucosa and in the gaps of single antral foveae in atrophic gastritis, 100x magnification 
fibroblastic cells and lymphocytes dominated over all other cellular forms, programmed differentiation characterized by immature fibroblastic cells $(p=0.018)$ with weak proteinsynthesizing function (Table I).

The reduced total number of mast cells was significant as well $(p=0.026)$, with the number of mature forms decreasing, which was observed in the near epithelial localisation, though a small amount of immature forms was also present around vascularly. Among mature mast cells mainly partially degranulated cells located in extracellular matrix were determined.

In the atrophic manifestations in lamina propria of AM, there was a reduced number of microcirculatory vessels compared to group $1(p=0.027)$. The vessels were generally determined in the subepithelial zone and between foveae, and in the area of glands there were single vessels. The observed vessels were dilated, without stasis and changed vascular wall, and endotheliocyte nuclei.

Morphological examination of AM in group 3 children showed the abnormality of regeneration processes accompanied by the generative layer thinning-the reduction in the total number of gastric foveae and the appearance of intestinal type foveae (Figure 3).

In addition, intestinal foveae were determined in the form of single focal spots in 8 of the 11 cases of the 8 -yearold children, in whom there were 1-3 intestinal foveae per 14 normal foveae. In 3 of the 11 cases (in children over 13 years) foveae of intestinal type occupied the most mucosa area, and there were 4-6 intestinal foveae per 10 gastric foveae that indicated multifocal IM. The epithelium of the foveae contained very few goblet cells of medium size, and single Paneth cells. The lumen of most of the cells was dilated, and the determined foveolar epithelium had dystrophic features and irregular mucoid production in the cells. Histochemical analysis of the histologic specimens of group 3 children showed a general reduced zone of PASpositive staining of granulocytes and superficial-foveolar mucous cells with decreased intensity in comparison with group $1(p=0.039)$, and with group $2(p=0.048)$. Few goblet exocrinocytes of metaplastic epithelium contained mainly PAS-positive secretion, and in some of them acid mucins were determined. In the presence of such characteristics, more expressed structural changes were observed both in an epithelial layer itself, and in the PMP in the form of deformed foveae with flattened epithelium and apically located nuclei of epitheliocytes.

The observed PAS-positive uniformity in the cytoplasm sections of all types of epithelium, including metaplastic (PAS-positive secretion of goblet cells), is a positive sign since it indicated the preservation of the functional properties characteristic of intact superficial-foveolar epithelium.

The study of proliferative activity of the superficial-foveolar epithelium in IM foci showed the revealed proliferation level to be significantly higher than in the comparison group $(p=0.019)$. The comparison of Ki-67-expression in gastric nonmetaplastic and metaplastic epithelium within one biopsy showed no significant changes $(p=0.071)$.

\begin{tabular}{|c|c|c|c|c|c|c|c|}
\hline \multirow{3}{*}{\multicolumn{2}{|c|}{$\begin{array}{l}\text { Parameters } \\
\text { Median }\end{array}$}} & \multirow{2}{*}{\multicolumn{2}{|c|}{$\begin{array}{l}\text { Nonatrophic gastritis } \\
\text { without IM }\end{array}$}} & \multicolumn{4}{|c|}{ Atrophic gastritis } \\
\hline & & & & \multicolumn{2}{|l|}{ with IM } & \multirow[b]{2}{*}{ Min-Max } & \multirow[b]{3}{*}{ 23-32 } \\
\hline & & \multirow{2}{*}{\begin{tabular}{|l|} 
Min-Max \\
22 \\
\end{tabular}} & \multirow{2}{*}{$\begin{array}{l}\text { Median } \\
17-28\end{array}$} & \multirow{2}{*}{$\begin{array}{l}\text { Min-Max } \\
28^{*}\end{array}$} & \multirow{2}{*}{\begin{tabular}{|l|} 
Median \\
$23-32$ \\
\end{tabular}} & & \\
\hline & Nonmetaplastic epithelium & & & & & $27.0^{*}$ & \\
\hline 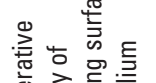 & $\begin{array}{l}\text { Metaplastic epithelium in } \\
\text { focal manifestation }\end{array}$ & - & - & - & - & $26.0^{*}$ & $23-30$ \\
\hline 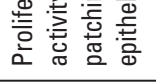 & $\begin{array}{l}\text { Metaplastic epithelium in } \\
\text { multifocal manifestation }\end{array}$ & - & - & - & - & 25.0 & $22-29$ \\
\hline \multicolumn{2}{|c|}{ Height of surface epithelium, $\mu \mathrm{m}$} & 30.0 & $26-33$ & 28.75 & $25.5-33$ & 28.75 & $24.0-31.5$ \\
\hline \multicolumn{2}{|c|}{ Infiltrate cell density, $\mathrm{mm}^{2}$} & 11155 & $9891-12426$ & $8507^{*}$ & $7731-9445$ & $8278^{*}$ & 6936-8932 \\
\hline \multicolumn{2}{|c|}{ Infiltrate lymphocytes $\mathrm{mm}^{2}$} & 4304 & $3027-5003$ & $2917^{*}$ & $2536-3365$ & $2795^{*}$ & $2175-3104$ \\
\hline \multicolumn{2}{|c|}{ Infiltrate plasma cells $\mathrm{mm}^{2}$} & 2329 & 1754-3102 & $1228^{*}$ & 884-1361 & $783^{* * * *}$ & $621-885$ \\
\hline \multicolumn{2}{|c|}{ Stroma fibroblasts immature $\mathrm{mm}^{2}$} & 435 & $336-609$ & $771^{*}$ & 516-854 & $895^{* * *}$ & 641-1009 \\
\hline \multicolumn{2}{|c|}{ Stroma fibroblasts mature $\mathrm{mm}^{2}$} & 1257 & $932-1385$ & 1359 & $975-1463$ & $1527^{*}$ & $1288-1641$ \\
\hline \multicolumn{2}{|c|}{ Stroma fibrocytes, $\mathrm{mm}^{2}$} & 1237 & $983-1381$ & $1329^{*}$ & $987-1386$ & $1508^{*}$ & $1354-1632$ \\
\hline \multicolumn{2}{|c|}{ Stroma macrophages, $\mathrm{mm}^{2}$} & 489 & $411-532$ & $386^{*}$ & $284-442$ & $362^{*}$ & $239-437$ \\
\hline \multicolumn{2}{|c|}{ Stroma mast cells, $\mathrm{mm}^{2}$} & 290 & 202-347 & $228^{*}$ & $143-285$ & $143^{* * * *}$ & 86-182 \\
\hline \multicolumn{2}{|c|}{ Infiltrate eosinophils, mm² } & 471 & $321-518$ & $189 *$ & 94-266 & $174^{*}$ & 83-263 \\
\hline \multicolumn{2}{|c|}{ Infiltrate neutrophils, $\mathrm{mm}^{2}$} & 249 & $146-278$ & $78^{*}$ & 31-108 & $73^{*}$ & 39-158 \\
\hline
\end{tabular}


Morphometric study of AM biopsies of group 3 (Table I) patients revealed significantly reduced indices of infiltrate cell density compared to those of both group 1 and group 2 ( $p=0.016$ and $p=0.035$, respectively). The feature of AM cell composition in the presence of IM areas was the increased number of fibroblastic cells, to a greater degree due to immature forms $(p=0.014)$. The number of mature fibroblasts was significantly increased compared to the comparison group only $(p=0.032)$. Mucosa interfoveolar space showed a growth in the number of fibrocytes compared to the comparison group ( $p=0.027)$ as well as group $2(p=0.034)$. It should be noted that the fibroblasts and fibrocytes localized paraepithelially were singly determined, therefore, their influence on the preservation of the basal membrane structure of the epithelium of foveae and glands appeared to be minimal. Also observed was the absence of macrophagefibroblast interaction, and significant reduction in the number of macrophages in AM in the atrophic gastritis patients with IM compared to the comparison group $(p=0.019)$ and group $1(p=0.028)$, which indicated their insufficient production of extracellular matrix components. Cells with lytic effect in the form of eosinophils and neutrophils were singly determined.

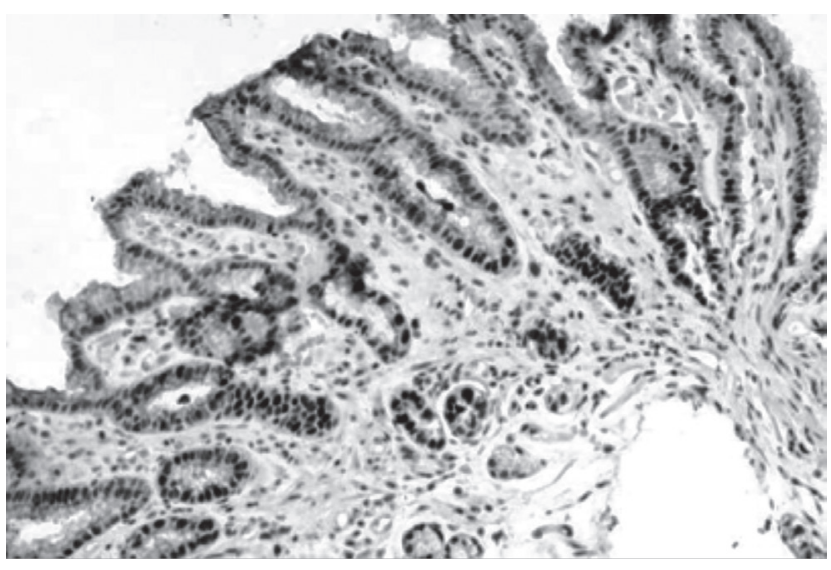

Figure 2. Immunohistochemical analysis: Ki-67 antigen exposure by foveolar epithelium of antral mucosa in atrophic gastritis, 100x magnification

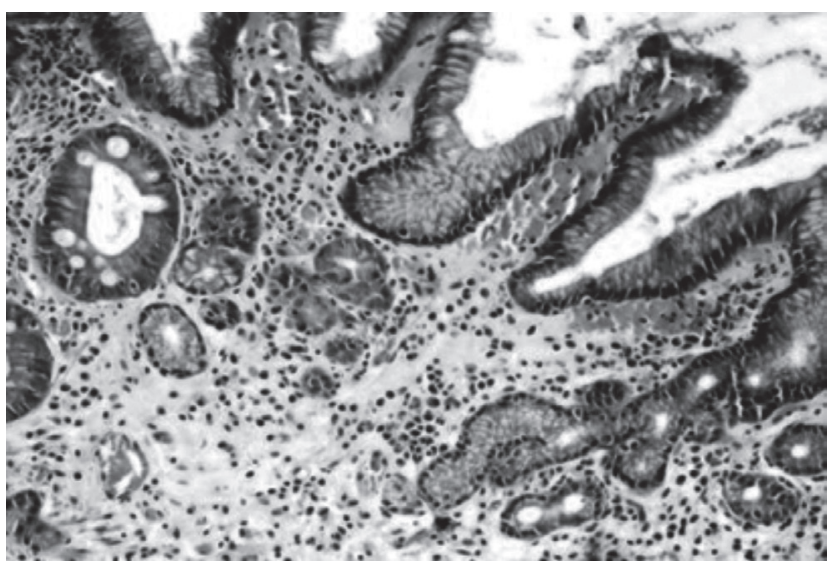

Figure 3. Chronic atrophic gastritis of antrum with intestinal metaplastic lesions of superficial-foveolar epithelium. Hematoxylin and eosin staining, 100x magnification
The analysis of mast cell population showed significant reduction in the total number of mast cells in the lamina propria of AM in group 2 children $(p=0.038$ ). Moreover, the number of maximally degranulated and degrading forms of mast cells was minimal (8.5\%), and the absence of those paraepithelially located indicated their insufficient functional activity in producing the components of basal membrane, particularly, heparin sulfate proteoglycan.

\section{Discussion}

Atrophic antrum-gastritis in children was characterized not only by the alteration of mucosal cytoarchitecture (the reduced volume of foveae and glands), but also by the reduced number of functionally mature cell forms responsible for the production of extracellular matrix components and basal membranes, the absence of which in paraepithelial localization results in the change of specific properties of basal membranes and, subsequently, the reduction of environmental resistance of epithelium. Appearance of epithelial zones with uncharacteristic signs: synthesis of sulphomucins and the shift of the proliferation compartment to the zone of the bottom of glands in atrophic gastritis can indicate further possible appearance of metaplastic transformation foci just in these areas. In atrophic gastritis with IM, the progression of the disturbances of intercellular and tissue-like interactions in AM occurs. Other revealed conditions in the environment of epitheliocytes seem to impose further growth of changes in the algorithm of intercellular existence, switching a cell synthetic potential to the production of proteins uncharacteristic of this type of epithelium that eventually results in the formation of a phenotype of a cell differentiated in another direction, strengthening the formation of intestinal metaplasia and changing its focal nature into multifocal.

\section{Conclusion}

Morphological changes in AM traced over a period of several years in the same patients in childhood and adolescence make it possible to conclude that the presence of frequently recurrent inflammatory process can result in persistent structural changes until atrophy occurs. However, the increase in the total number of fibroblastic cells with immature forms prevailing, and adequate state of microvasculature suggest an irreversible atrophic process in childhood.

\section{Ethics}

Ethics Committee Approval: The study was approved by the Ethics Committee of our Research Institute (Approval number: 2007/28), Informed Consent: Consent form was filled out by all participants.

Peer-review: Externally peer-reviewed. 


\section{Authorship Contributions}

Concept: Natalia Yurievna Shirokova, Design: Diana Anatolyevna Davydova, Data Collection or Processing: Natalia Yurievna Orlinskaya, Analysis or Interpretation: Natalia Yurievna Shirokova, Diana Anatolyevna Davydova, Literature Search: Natalia Yurievna Orlinskaya, Writing: Natalia Yurievna Shirokova.

Conflict of Interest: No conflict of interest was declared by the authors.

Financial Disclosure: The authors declared that this study received no financial support.

\section{References}

1. Dohil R, Hassall E, Jevon G, Dimmick J. J Pediatr Gastroenterol Nutr 1999;29:378-94.

2. Brigic E, Hadzic D, Mladina N. Childhood and Coress model of carcinogenesis. Med Arch 2012;66:375-7.

3. Guarner J, Bartlett J, Whistler T, et al. Can pre-neoplastic lesions be detected in gastric biopsies of children with Helicobacter pylori infection? J Pediatr Gastroenterol Nutr 2003;37:309-14.

4. Correa P. The biological model of gastric carcinogenesis. IARC Sci Publ 2004;301-10.

5. Ricuarte O, Gutierrez O, Cardona H, Kim JG, Graham DY, El-Zimaity HM. Atrophic gastritis in young children and adolescents. J Clin Pathol 2005;58:1189-93.

6. Hassall E, Dimmick JE. Unique features of Helicobacter pylori disease in children. Dig Dis Sci 1991;36:417-23.

7. Satarkar RP, Sawant P, Nanivadekar S, Shroff C. Helicobacter pylori and intestinal metaplasia of gastric mucosa. Indian $\mathrm{J}$ Gastroenterol 1997;16:16-7.

8. Ierardi E, Francavilla R, Panella C. Effect of Helicobacter pylori eradication on intestinal metaplasia and gastric epithelium proliferation. Ital J Gastroenterol Hepatol 1997;29:470-5.

9. Ohkuma K, Okada M, Murayama H, et al. Association of Helicobacter pylori infection with atrophic gastritis and intestinal metaplasia. J Gastroenterol Hepatol 2000;15:110512.

10. Brittan M, Wright NA. Gastrointestinal stem cells. J Pathol 2002;197:492-509.

11. Ruiz B, Garay J, Correa P, et al. sMorphometric evaluation of gastric antral atrophy; improvement after cure of Helicobacter pylori infection. Am J Gastroenterol 2001;96:3281-7.

12. Yeh $L Y$, Raj $M$, Hassan $S$, et al. Chronic atrophic antral gastritis and risk of metaplasia and dysplasia in an area with low prevalence of Helicobacter. Indian J Gastroenterol 2009;28:49-52.

13. Reis CA, David L, Correa $P$, et al. Intestinal metaplasia of human stomach displays distinct patterns of mucin (MUC1, MUC2, MUC5AC, and MUC6) expression. Cancer Res 1999;59:1003-7.
14. Jass JR, Filipe MI. The mucin profiles of normal gastric mucosa, intestinal metaplasia and its variants and gastric carcinoma. Histochem J 1981;13:931-9.

15. Smith JL, Dixon MF Is subtyping of intestinal metaplasia in the upper gastrointestinal tract a worthwhile exercise? An evaluation of current mucin histochemical stains. $\mathrm{Br} J$ Biomed Sci 2003;60:180-6.

16. Dinis-Ribeiro M, Lopes $C$, da Costa-Pereira A, et al. A follow up model for patients with atrophic chronic gastritis and intestinal metaplasia. J Clin Pathol 2004;57:177-82.

17. Kapadia CR. Gastric atrophy, metaplasia and dysplasia: a clinical perspective. J Clin Gastroenterol 2003;36(5 Suppl):S29-36.

18. El-Zimaity H. Gastritis and gastric atrophy. Curr Opin Gastroenterol 2008;24:682-6.

19. Unger Z, Pronai L, Szaleczky E, Zagoni T, Molnar B, Tulassay $Z$. Effect of Helicobacter pylori infection and eradication on proliferative kinetics of the gastric mucosa. Orv Hetil 2000;141:2695-700.

20. Unger Z, Molnar B, Szaleczky E, et al. Effect of Helicobacter pylori infection and eradication on gastric epithelial cell proliferation and apoptosis. J Physiol Paris 2001;95:355-60.

21. Lerardi E, Francavilla A, Balzano T, et al. Effect of Helicobacter pylori eradication on gastric epithelial proliferation. Relationship with ras oncogene p21 expression. Ital $J$ Gastroenterol Hepatol 1997;29:214-9.

22. Gillett $P$, Hassall E. Pediatric gastrointestinal mucosal biopsy. Special considerations in children. Gastrointest Endosc Clin N Am 2000;10:669-712, vi-vii.

23. Fichman S, Niv Y. Histological changes in the gastric mucosa after Helicobacter pylori eradication. Eur J Gastroenterol Hepatol 2004;16:1183-8.

24. Ozturk Y, Ozer E, Lebe B, Bekem O, Buyukgebiz B. Immunohistochemical evaluation of p53 expression and proliferative activity in children with Helicobacter pylori associated gastritis. J Pediatr Gastroenterol Nutr 2005;40:467-70.

25. Micu G, Staniceanu F, Zurac $S$, et al. Regression of precancerous epithelial alteration in patients with Helicobacter pylori chronic gastritis. Rom J Intern Med 2010:48:89-99.

26. Rugge M, de Boni M, Pennelli G, et al. Gastritis OLGA-staging and gastric cancer risk: a twelve year clinico-pathological follow-up. Aliment Pharmacol Ther 2010;31:1104-11.

27. Ramirez-Mendoza $P_{1}$ Gonzalez-Angulo J, Angeles-Garay $U$, Segovia-Cueva GA. Evaluation of Gastritis Atrophy. Comparison Between Sidney and OLGA Systems. Rev Med Inst Mex Seguro Soc 2008;46:135-9.

28. Rugge $M, \operatorname{Kim} J G$, Mahachai $\bigvee$, et al. OLGA gastritis staging in Young Adults and country specific gastric cancer risk. Int J Surg Pathol 2008;16:150-4.

29. Naish SJ. Immunochemical staining methods. DAKO Corporation. 1989, 41

30. Dabbls DJ. (Ed) Diagnostic immunohistochemistry. Edinburg: Churchill Livingstone, 2002, 673. 